\title{
Interactive dynamic tests for evaluating the development of spatial abilities in high school
}

\section{LÁSZLÓ BUDAI}

\section{ABSTRACT.}

In the last 10-15 years the number of studies examining spatial abilities of students has increased rapidly. The development of the spatial ability system components is important since these skills are used in everyday life and in order to reach our goal (position) people need good spatial perception in many cases. GeoGebra is a suitable and effective tool for developing these abilities. New methods for measuring these abilities can be developed that would be better adapted to today's needs. The dynamic and interactive adaptation of available GeoGebra tests for measuring spatial abilities would place these measurements on a new ground. However, there are many unanswered questions. The technical background, results and experiences of pilot a test of these methods are presented here.

\section{REFERENCES}

[1] Hoffmann, M., Németh, B., and Sörös, Cs., Typical Mistakes in Mental Cutting Test and Their Consequences in Gender Differences, Teaching Mathematics and Computer Science, 5 (2007), No. 2, 385-392

[2] Hoffmann, M., and Németh, B., Gender differences in spatial visualization among engineering students, Ann. Math. Inform., 33 (2006), 169-174

[3] Lord, T. R., Enhancing the Visuo-spatial Aptitude of Students, Journal of Research in Science Teaching, 22 (1985), $395-405$

[4] McGee, M. G., Human Spatial Abilities: Psychometric studies and environmental, genetic, hormonal and neurological influences, Psychological Bulletin, 86 (1979), 899-918

[5] Nagy-Kondor, R., Spatial ability of engineering students, Ann. Math. Inform., 34 (2007), 113-122

[6] Nagy-Kondor, S., Engineering students' spatial abilities in Budapest and Debrecen, Ann. Math. Inform., 40 (2012), 187-201

[7] Nagy-Kondor, R., Spatial Ability, Descriptive Geometry and Dynamic Geometry Systems, Ann. Math. Inform., 37 (2010), 199-210

[8] Schröcker, H.-P., Stachel, H., Tsutsumi, E., and Weiss, G., Evaluation of Students' Spatial Abilities in Austria and Germany, J. Geom. Graph., 9 (2005), 107-117

BUDAPEST BUSINESS SCHOOL, UNIVERSITY OF APPLIED SCIENCES

COLlege of INTERNATIONAL MANAGEMENT AND Business

INSTITUTE OF BUSINESS TEACHER TRAINING AND PEDAgOgY

DisY LAJOS S. 22-24. 1165 BUDAPEST - XVI. DISTR.

E-mail address: budai0912@gmail.com 